\section{THE BRITISH EXPLOSIVES INDUSTRY.1}

A VALUABLE addition to the literature on explosives has been published under the auspices of the seventh International Congress of Applied Chemistry by its explosives section, with Mr. Brayler Hodgetts as editor. It owes its inception to Mr. Oscar Guttmann, to whom the publishers pay a well-deserved

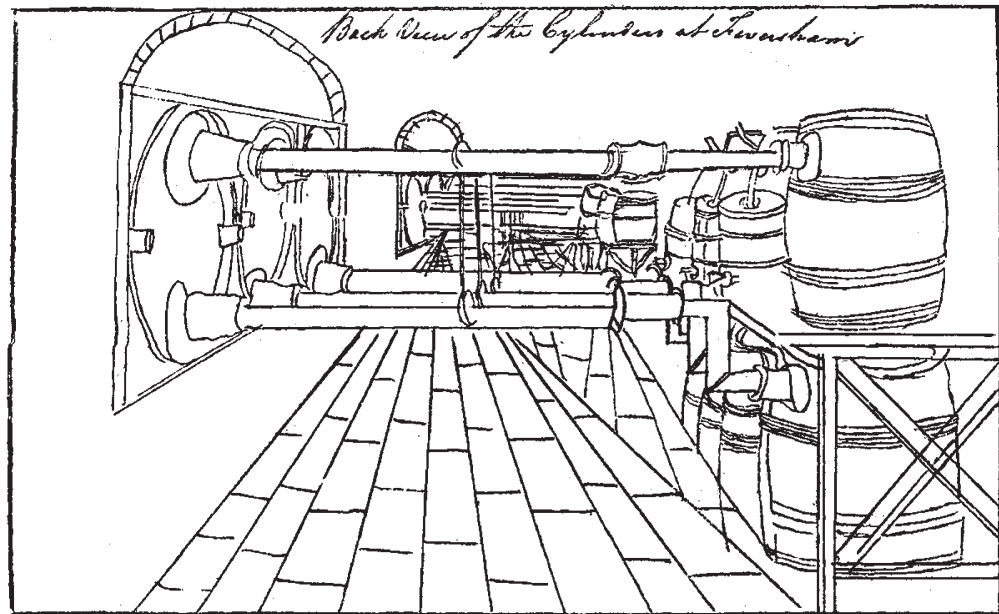
FiG. 1.-Charcoal Chambers in ${ }^{1798}$. Back View. Reduced from "The Rise and Progress of the
British Explosives Industry." strictions on manufacture and storage, the supervision was very lax, leading to great carelessness in the manufacture and handling of such dangerous substances. Colonel Moody's report on the disastrous explosion of powder magazines on the river-bank at Erith in 1864 (from which report some startling extracts are given) fully emphasised the necessity for more stringent regulations, and led in October of that year to the appointment of Colonel Boxer to "inspect and examine any mill, magazine or place" in which any kind of explosive was manufactured or kept. Later, a further disaster at Birmingham, by which fifty-three lives were lost, resulted in the appointment of permanent inspectors on the recommendation of the late Colonel Sir V. D. Majendie K.C.B., who, as chief inspector, became so well known to the public at the time of the Fenian outrages. The Explosives Act of 1875 was the final outcome of these disasters, an Act which has proved of the greatest value through the tactful administration of the inspectors and the conscientious manner is which its provisions have beet observed by the industry.

Special mention must be madk of the bibliography and of the chronology. It is claimed for the former that it gives a complete tribute for his able assistance and the facilities he/list of the books on explosives published in Enghas afforded them by placing his unique and valuable library at their disposal.

All who have been associated with the compilation of the work are to be highly congratulated on having produced a volume which will certainly fulfil the hope expressed by Captain Tulloch in his preface, that it will " in years to come be looked upon as a work of reference connecting the past with the future," for all will agree with him, after perusing it, that " it is the only work of the kind containing so complete a history of the manufacture of explosives in this country."

The book is divided into two main sections, historical and descriptive. In the former are articles devoted to each of the principal explosives, and such related subjects as percussion caps, safety fuses, and fireworks, contributed by writers specially competent to deal with each. It is impossible to single out any one article for comment, but the contributions of Mr. G. W. Macdonald on the literature relating to researches on gunpowder, nitroglycerine, and nitrocellulose, with the full references to the original papers, will prove of considerable value.

Outside of what may be regarded as the purely scientific or technical articles, that on legislation, contributed by the editor, is of great interest. Although prior to 1860 there had been many Acts placing re-

1 "The Rise and Progress of the British Explosives 'ndustry," Published unjer the Auspices of the Seventh International Congress of Applied Chemistry bv its Explosives Section. Pp. xiv +418 . (London: Whittaker and Co., rgog.) Pi ice r5s. net.

NO. 2076 , VOL. 8I]

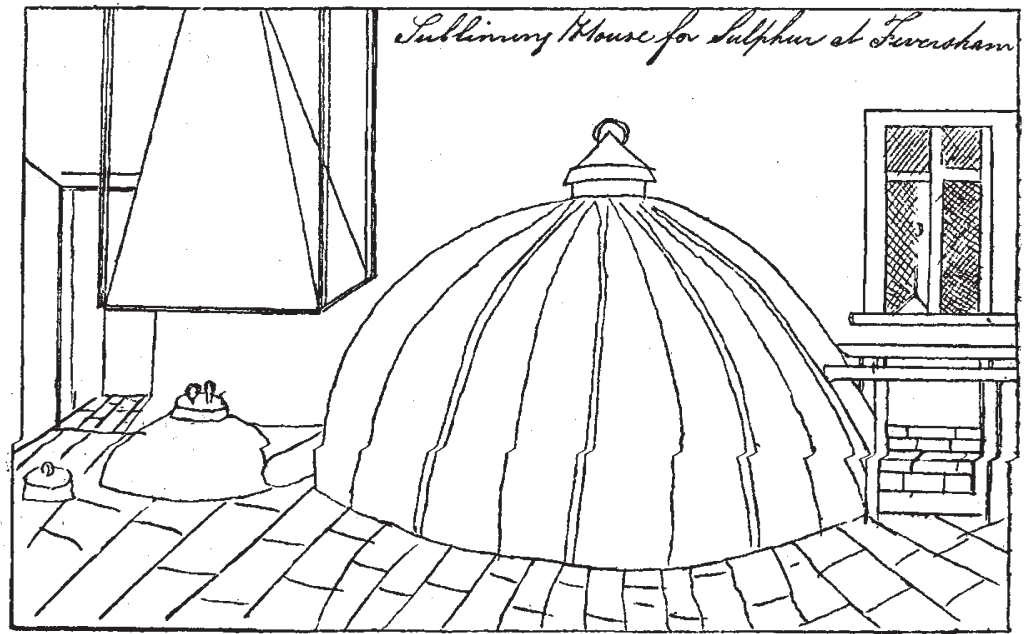

FIG. 2.-Sulphur Subliming Chamber in r798. Side View Reduced from "The Rise and Progress of the British Explosives Industry."

extremely quaint and of great interest. This chronology should appeal to the antiquarian equally with the student of applied science:

In the second section of the book, devoted to description of existing factories, the information as to development, specialities of manufacture, organisation, \&c., is very complete. Space only permits of reference to the articles dealing with Government 
establishments, in each case written by the superintendent - the Royal Laboratory, Woolwich, by Colonel Sir Hilaro Barlow; the Royal Gunpowder Factory, Waltham Abbey, by Colonel Sir Frederic Nathan; and the recently re-constituted Research Department at Woolwich, by Major H. Mansell. The history and development of these important Government establishments will prove of general interest. The Royal Laboratory alone must be prepared to manufacture at short notice some 3000 articles of approved design for war purposes. An interesting comparison of the cost of shells may be quoted. In I849 the finished shell for 8-inch smooth-bore guns alarmed the authorities. It was iss. $3 \frac{1}{2} d$. The modern I2-inch shell costs about 29l. when completed!

One extract may be permitted from Colonel Jocelyn's article on military fireworks. "In the Mathematical Society of London a rule existed which imposed a fine of sixpence on any member who should let off fireworks in the place of meeting." This but reflects the playfulness of the times when Pepys and his friends enjoyed pelting each other and "the people over the way " with fireworks.

The book is illustrated with some fine portraits of those who have been prominently associated with the industry, and a number of old illustrations of powdermaking processes, which greatly add to the value of the work. Those selected for reproduction are of more general interest than others relating to powder manufacture itself. The recovery of by-products from the carbonisation of wood, as shown in the first illustration (Fig. I), cannot fail to be of interest to chemists, as will also the sulphur-refining plant (Fig. 2) with its retort, fume-hood, and condensing chamber.

J. S. S. B.

\section{DANISH RESEARCHES ON THE EEL AND} THE PLAICE.

THE "Kommission for Havunders $\varnothing$ gelser," the official body entrusted with the execution of Denmark's share in the international exploration of the sea, devotes a considerable portion of its resources in endeavouring to solve certain important problems connected with the natural history of the eel and the plaice. These investigations are producing very definite results.

'Two papers recently contributed by Dr. Johs. Schmidt to the "Meddelelser" of this commission considerably advance our knowledge of the metamorphosis and distribution of the larvæ of the eel and other muræenoids. Since the publication of Dr. Schmidt's notable treatise of 1906, in which the distribution of the larvæ of the eel in the Atlantic, west of Europe, was described in detail for the first time, a large quantity of new material has been collected by means of the Danish research steamer Thor.

The new captures included more than 50o larvæ of the common eel, 300 of which were in different stages of metamorphosis. The material previously dealt with (in the treatise of 1906) consisted of 265 specimens, only eight of which showed an advance on the leptocephalus stage. Taking the captures of 1905 and 1 Meddelelser fra Kommissionen for Havunders $\phi$ gelser. Serie Fiskeri. Bind iii., Nos. J, 3. 5, and 6.

No. I. C. G. Joh. Petersen: On the Larval and Post-larval Stages of Nome Pleuronectidæ (Zetgopterus, Arnoglossus, Solea). With two plates.
soly

No. 3. Johs. Schmidt : Remarks on the Metamorphosis and Distribution of the Larva of the Eel (Anguilla vulgaris, Turt.). With one plate and one chart.

e chart.

No. 5. A. C. Johansen: Contributions to the Biology of the Plaice, with special regard to the Danish Plaice Fishery. iv. Is the Plaice Indigenous

No. 6. Johs. Schmidt: On the Occurrence of Leptocephali (Larval Murenoids) in the Atlantic W. of Europe. With two plates and one

$$
\text { NO. } 2076 \text {, vOL. 8I] }
$$

I906 together, the following is a list of the leptocephali of murænoids so far taken by the Thor:-Leptocephalus of eel, 790; of Synaphobranchus (deep-sea eel), I26; of the conger, 32 ; other leptocephali belonging to four unknown species, 12.

Confining our attention to the common eel, it may be said that these new researches throw light on obscure points, amend former statements, and fill up several gaps. The more important new facts may be briefly summarised as follows :-

(r) In May all the leptocephali were in stage $\mathbf{I}$; in September they were mostly in various stages of metamorphosis. This implies that the propagation of the eel is limited in the main to a certain portion of the year, as is the case with most other fishes.

(2) In September the later stages were found further towards the shore than the earlier stages. This indicates shoreward migration during metamorphosis.

(3) It was found that both leptocephali and glass eels were larger in the southern than in the northern part of the area of distribution.

(4) Whereas in the treatise of 1906 calculations of the shrinkage of the larvæ during metamorphosis were based on fragmentary material, belonging to different regions and different years' groups, it is now possible to say definitely that the diminution in length involved in the retrogressive metamorphosis amounts to $\mathrm{I} \mathrm{cm}$. This average is based on a large number of measurements of leptocephali and glass eels from the same region, and belonging to the same year's group. Further, weighings of leptocephali and glass eels prove for the first time that the metamorphosis involves an actual loss of substance, the dry-weight of glass eels being only one-third of that of leptocephali.

(5) There is good evidence that the larvæ execute diurnal vertical movements in the sea, coming nearer the surface at night than during the day.

(6) There are places where the larvæ of the eel are the commonest fish, just as we find in the case of the different species of gadoids, each of which (as we know from Dr. Schmidt's own investigations) chooses its own conditions of depth, salinity, and temperature for spawning purposes. Thus the specific trait shows itself in the selection of spawning habitat, as well as in anatomical and physiological peculiarities.

The first and final chapters of this weird and fascinating history have yet to be written. Neither the eggs nor the spawning adults have been found, though there is good reason to believe that the former are bathypelagic, i.e. floating at considerable depths, as is the case with other murænoids, Argentines, and other deep-sea fishes. The discovery of these things can only be a matter of time and resources. Ships and men are not lacking, apparently.

In regard to other murænoids, the recent irivestigations show that the conger is a more southern form than the eel. Its larvæ do not range further north than Rockall, whereas the leptocephali of the eel extend to the latitude of the Færöes. The larvæ of the conger do not occur over such great depths as those of the eel. They show the same inshore movement during metamorphosis, there being a close connection between depth and pre-anal length.

The larvæ of the deep-sea eel (Synaphobranchus pinnatus) were never taken so near the surface as the leptocephali of the common eel, never higher in the water than Ioo metres. In the case of this species there is nothing to suggest shorewards migration. During metamorphosis the larvæ sink to the bottom in deep water, where fully-developed eels of this species were caught in large numbers over a wide area of the north-east Atlantic.

Of the other leptocephali (four kinds) it is impossible to say at present to what species they belong, 